\title{
Economic Analysis of Moringa in Tamil Nadu
}

\author{
Dr. T. Rajendran \\ Assistant Professor, Tamil Nadu Agricultural University \\ Agricultural College and Research Institute, Killikulam, Vallanad
}

\section{ABSTRACT}

Tamil Nadu is the pioneering state in so much as it has varied genotypes from diversified geographical areas, as well as introductions from Sir Lanka. Farmers found that growing moringa crops during summer season was remunerative. Thus, moringa gained a foothold as a summer vegetable. Its unique flavour and aroma became very popular. For South Indian any meal without moringa and pulses is considered incomplete. The demand for the moringa pod also increased due to increased urban settlements and migration of people to urban colonies. Based on the significance of moringa in the human diet this study might more viable with the specific objectives of to assessing the marketing strategies for promotion Periyakulam annual moringa in Tamil Nadu.

This study revealed that the price fluctuation in moringa is to the extent of ten times. The moringa production is scattered. The commercial pure crop cultivation is practiced only in selected areas in Tamil Nadu. Being perishable in nature, the produce has to be sold within a short period. Thus in the market, farmers are price takers and are in risk at disadvantages. Group monopsony behaviour of few well established trades indicated that the price made for moringa trade is unfavourable to farming community. Hence, supply chain management has to be effectively arranged for getting due share in the consumer price.

Keywords: marketing strategies, price fluctuation, marketing cost, market channel, market structure, b-c ratio

\section{Introduction}

Tamil Nadu, moringa was cultivated as sole trees in homesteads, round cattle sheds, on farm boundaries, and as isolated plants in fences and as groups of trees on village waste lands. In the early 1990s in southern Tamil Nadu people started growing perennial moringa types - Moolanoor as an intercrop on field scale and their allies were cropped with vegetables and Sorghum. This system evolved as moringa offered some protection to alley crops from drying winds during summer and moringa provided some additional income. With the migration of people from south to north India, and the elsewhere in the world the demand for moringa picked up.

Farmers found that growing moringa crops during summer season was remunerative. Thus, moringa gained a foothold as a summer vegetable. Its unique flavour and aroma became very popular. For South Indian any meal without moringa and pulses is considered incomplete. The demand for the moringa pod also increased due to increased urban settlements and migration of people to urban colonies. Based on the significance of moringa in the human diet this study might more viable with the specific objectives of to assessing the marketing strategies for promotion Periyakulam annual moringa in Tamil Nadu.

Tamil Nadu is one of the largest producers of moringa with an annual production of 3.6 lakh tonnes of tender fruits from an area of $7343 \mathrm{ha}$. Among the districts in the state, Tuticorin leads in both area and production [1646 ha] followed by Dindigul [1440 ha], Theni [1397 ha], Karur [810 ha] and Erode [633 ha]. Madurai, Perambalur, Tirunelveli and Cuddalore also have considerable area under moringa. The remaining districts have a total area of 333 ha only.

Diverse varieties and cultivars types of moringa are found in specific parts of India. Among the released varieties and local types, only PKM 1 and PKM 2 have the most popular and better export preference.

\section{Market Structure}

The significant variables perceived in influencing the structural characteristics of moringa markets are i. Attentiveness ratio of the buyers ii. Production and marketed surplus and iii. Perishability of the product.

\section{Marketing Channel of Moringa}

\section{Channel I}

Farmer / Producer $\rightarrow$ Petty trader $\rightarrow$ Wholesaler $\rightarrow$ Commission agents $\rightarrow$ Retailer $\rightarrow$ Consumer 


\section{Channel II}

Farmer / Producer $\rightarrow$ Commission agents $\rightarrow$ Wholesaler $\rightarrow$ Retailer $\rightarrow$ Consumer

\section{Channel III}

Farmer / Producer $\rightarrow$ Commission agents $\rightarrow$ Wholesaler $\rightarrow$ Commission agents $\rightarrow$ Processor

The middle man plays vital roles in marketing of moringa thus the farmers were getting lower price of their produce. Hence, the middle man makes of more profits.

\section{Marketing Cost}

Based on farm survey at Ethakoil, Andipatti taluk, Theni district from Th. Samuthiram \& Th. Chinnan Moringa as sample farmers. Moringa farmers are incurring higher marketing cost while middleman plays major role in getting higher profits as shown in table 1 below:

Table 1. Marketing cost of Moringa

\begin{tabular}{|c|l|c|}
\hline S. No & Particulars & Marketing Cost [Rs.] \\
\hline 1 & Labour cost for - Male / Female & $200 / 70$ \\
\hline 2 & Packaging materials like gunny bag & $10-13$ \\
\hline 3 & Transport cost of 50 kg and 100 kg gunny bags & $15 \& 20$ \\
\hline 4 & Pesticide spraying cost for 12litres tank & 20 \\
\hline 5 & The price of the produce in the intense production season & $5-7$ \\
\hline 6 & least production [October, November and December] & $80-90$ \\
\hline
\end{tabular}

\section{Benefit-Cost Ratio}

Based on the farm survey at Kullapuram village, Andipatty taluk, Theni district of Th. Sethuram Ponnusamy, Mobile Number: 99445 51825. He is cultivating annual moringa of about one acre past 5 years with very profitable manner.
Table 2. Benefit - Cost Ratio of Moringa

\begin{tabular}{|c|l|c|}
\hline $\begin{array}{c}\text { S. } \\
\text { No }\end{array}$ & Particulars & $\begin{array}{c}\text { Cost } \\
\text { [Rs.] }\end{array}$ \\
\hline 1 & Seeds & 750 \\
\hline 2 & Field preparation & 1500 \\
\hline 3 & Labours & 3000 \\
\hline 4 & Fertilizers \& Pesticides & 10000 \\
\hline 5 & Weeding Harvesting \& & 5750 \\
\hline 6 & $\begin{array}{l}\text { Irrigation , } \\
\text { Marketing }\end{array}$ & 25,000 \\
\hline 7 & $\begin{array}{l}\text { Total cost of the production } \\
\text { Yield : 9 tonnes / acre x Rs. 7/- kg } \\
\text { of price }\end{array}$ & 63,000 \\
\hline 9 & Benefit - Cost Ratio & $1: 2.52$ \\
\hline
\end{tabular}

Source: Farm survey 
Form the table 2, the moringa farms incurred the expenditure of one rupee could get the profit of about rupee 2.52 being an economic viable one.

\section{Marketing Strategy for Local Market for Moringa}

Market distribution for domestic and international

i. Farmer / Producer $\rightarrow$ Petty trader [broker] $\rightarrow$ Exporter

ii. Farmer / Producer $\rightarrow$ Wholesaler $\rightarrow$ Processor $\rightarrow$ Exporter

High quality drumsticks of export quality are available with our growers in large quantity. The moringa growers are generally having smaller holdings [less than one hectare]. They require to sell their produce to meet out the other domestic commitments. Since, they are selling their produce in very nearest market with-middle man at the lowest price. Major local markets play at Andipatti, Themmarasanayakkanur and Koyempedu.
Some of the marketing strategies for local market for moringa are:

moringa growers might produce in the need based of consumer's demand and preference.

$\checkmark$ Pods and leaves are suited for local markets.

Collective systems of marketing to be followed.

More cautious about the price of produce in different other nearest market.

Commercial production of immature pods for processing is a large industry in India with about 1.2 million MT produced annually on 38,000 ha. Most of the moringa are exported to southern parts of Tamil Nadu as shown in table 3 below

\section{Export Marketing Strategy of Moringa}

Table 3. Export Destination for Moringa

\begin{tabular}{|c|l|l|}
\hline S. No & Area & Export Destination \\
\hline 1 & Dindugul & $\begin{array}{l}\text { Oddanchatram, Vedachanthur \& Bangaloru } \\
\text { Market }\end{array}$ \\
\hline 2 & Erode & Moolanur Moringa Market \\
\hline 3 & Karur & Bangaloru Market \& Mumbai Market \\
\hline 4 & Theni & Andipatti \\
\hline 5 & Madurai & $\begin{array}{l}\text { Palamedu Moringa - Usilampatti - Koyempedu } \\
\text { Market }\end{array}$ \\
\hline 6 & Tirunelveli & $\begin{array}{l}\text { Jaffna Moringa by Shipment to Gulf countries } \\
\text { like Dubai }\end{array}$ \\
\hline 7 & Trichy & Kodikal Moringa Market \\
\hline
\end{tabular}

Table 3 prove that, there is ample market for drumsticks in metro cities like Hyderabad, Mumbai, Pune, Nashik, Surat and others. Drumsticks have more demand in Rajasthan also. In addition, drumsticks have highest demand in Singapore. Since the drumsticks has antibiotic such as Penicillin it has much more demand in countries like England, Japan,
Canada, Bangkok, Doha, Dubai, Baharen, Musket and Daman etc.,

Some of the marketing strategies for export market for moringa are

Government might be formulating procurement centres of moringa farms. 
$\checkmark \quad$ Leaves, medicinal and value-added products have potential shipment to North America and Asia.

$\checkmark$ Provide the timely market information need based.

Moringa is relatively to grow organically and organic certification may increase consumer appeal.

$\checkmark$ Based on super food trends, producers of processed juices and smoothes may also be a potential high-value market for moringa growers.

$\checkmark$ Construct the formal quality standards for moringa products, including oil.

$\checkmark$ Food safety certification may be required by some wholesale and retail venues for fresh leaf and pod sales.

\section{Conclusions}

Community education about moringa's valuable products needs to be carried out, especially for import replacement. Annual moringa should be planted in April, May because drumstick fetches higher price in the months of November, December and January. There is ample market for drumsticks in local and export level, metro cities like Hyderabad, Mumbai, Pune, Nashik, Surat and others. Drumsticks have more demand in Rajasthan also. In addition, drumsticks have highest demand in Singapore.

The price fluctuation in moringa is to the extent of ten times. The moringa production is scattered. The commercial pure crop cultivation is practised only in selected areas in Tamil Nadu. Being perishable in nature, the produce has to be sold within a short period. Thus in the market, farmers are price takers and are in risk at disadvantages.

\section{Reference}

Farm Survey

Statistical Hand book of Tamil Nadu 